Review Article

\title{
Plesiomonas: A Review on Food Safety, Fish-Borne Diseases, and Tilapia
}

\author{
Alejandro De Jesús Cortés-Sánchez ${ }^{D},{ }^{1}$ Luis Daniel Espinosa-Chaurand $\left(\mathbb{D},{ }^{1}\right.$ \\ Mayra Díaz-Ramirez $\mathbb{D}^{2}{ }^{2}$ and Erika Torres-Ochoa $\mathbb{D}^{3}$ \\ ${ }^{1}$ Consejo Nacional de Ciencia y Tecnología (CONACYT), \\ Unidad Nayarit del Centro de Investigaciones Biológicas del Noroeste (UNCIBNOR+), Calle Dos, No. 23, Cd. del Conocimiento, \\ Av. Emilio M. González C.P., Tepic 63173, Nayarit, Mexico \\ ${ }^{2}$ Universidad Autónoma Metropolitana, Unidad Lerma, Departamento de Ciencias de la Alimentación, \\ División de Ciencias Biológicas y de la Salud, Av. de las Garzas 10, Col. El panteón, C.P. 52005, Lerma de Villada, \\ Estado de México, Mexico \\ ${ }^{3}$ Universidad Autónoma de Baja California Sur, Departamento Académico de Ingeniería en Pesquerías, \\ Carretera al sur Km 5.5. Colonia el Mezquitito, C.P. 23080, La Paz, Baja California Sur, Mexico
}

Correspondence should be addressed to Alejandro De Jesús Cortés-Sánchez; alecortes_1@hotmail.com

Received 4 May 2021; Revised 31 August 2021; Accepted 8 September 2021; Published 21 September 2021

Academic Editor: Jesus L. Romalde

Copyright (C) 2021 Alejandro De Jesús Cortés-Sánchez et al. This is an open access article distributed under the Creative Commons Attribution License, which permits unrestricted use, distribution, and reproduction in any medium, provided the original work is properly cited.

Fish and fish products are considered a fundamental part of the human diet due to their high nutritional value. Food-borne diseases are considered a major public health challenge worldwide due to their incidence, associated mortality, and negative economic repercussions. Food safety is the guarantee that foods will not cause harm to the health of those who consume them, and it is a fundamental property of food quality. Food safety can be at risk of being lost at any stage of the food chain if the food is contaminated by pathogenic microorganisms. Many diverse bacteria are present in the environment and as part of the microbiota of food that can be transmitted to humans during the handling and consumption of food. Plesiomonas shigelloides has been mainly associated with outbreaks of gastrointestinal diseases due to the consumption of fish. This bacterium inhabits the environment and aquatic animals and is associated with the microbiota of fish such as tilapia, a fish of importance in fishing, aquaculture, commercialization, and consumption worldwide. The purpose of this document is to provide, through a bibliographic review of databases (Scopus, Web of Science, and Google Scholar, among others), a general informative perspective on food-borne diseases and, in particular, the consumption of fish and tilapia. Diseases derived from contamination by Plesiomonas shigelloides are included, and control and prevention actions and sanitary regulations for fishery products established in several countries around the world are discussed to promote the safety of foods of aquatic origin intended for human consumption and to protect public health.

\section{Introduction}

Feeding is an essential act in the life of humans. However, it is essential that the food to be consumed is safe and provides the necessary nutrients to perform basic functions (energetic, structural, functional, and regulatory) and maintain health $[1,2]$.

Foods can be disease transmitters, as foods can be contaminated by different microorganisms and/or toxins that, when ingested, become potentially dangerous. Thus, food safety has become an elementary property that involves public health, the well-being of the population, and the world economy [1].

In recent years, fish meat has been considered an alternative to the consumption of beef, pork, and poultry due to the demand for a healthier lifestyle [1]. In the search to satisfy the growing demand for fish, food safety is an essential element to consider since these animals can be 
vehicles for the transmission of various pathogens, such as Salmonella spp., Vibrio spp., Aeromonas spp., Campylobacter spp., Shigella spp., Yersinia spp., Clostridium spp., Bacillus cereus, Escherichia coli, Listeria monocytogenes, Staphylococcus aureus, and Plesiomonas shigelloides, among others, which have been responsible for numerous cases and outbreaks of food-borne diseases in humans worldwide [3-6].

In foods such as fish, the presence of a high content of water and nutrients (proteins, lipids, vitamins, and minerals), along with a $\mathrm{pH}$ close to neutrality and warm temperatures, provides a favorable environment for rapid microbial growth [5, 7]. Microorganisms can inhabit and survive in many natural environments and can be transferred to food, contaminating them at different stages of the food chain through soil, air, water, insects, animals, and humans $[3,5,8]$. The absence of or inadequate hygienic conditions and practices in production, processing, and conservation favor the transfer of pathogenic microorganisms to food, giving rise to important health risks to the consumer [5, 7-9].

In this context, the purpose of this document is to provide, through a bibliographic review of different databases (Scopus, Web of Science, Redalyc, SciELO, and Google Scholar, among others), a general informative perspective related to members of the food chain (producers, processors, handlers, academia, and the general public) on diseases transmitted by food and, in particular, fish and tilapia, where tilapia is considered an important product in capture fisheries and aquaculture activities with worldwide commercialization and consumption. Food-borne diseases resulting from contamination by Plesiomonas shigelloides, control and prevention actions such as the implementation of the Hazard Analysis and Critical Control Points (HACCP) system, microbiological analysis, and the sanitary regulations established in several countries around the world for fish and fish products are specifically considered to promote the safety of foods of aquatic origin intended for human consumption and to protect public health.

\section{Food-Borne Diseases}

Food safety guarantees that a food will not cause harm or disease to the person who consumes it, and it is considered, along with the nutritional, sensory, and commercial characteristics, a component of the total quality of a food [10].

A food-borne disease (FD) is defined as a syndrome caused by the ingestion of food and/or water with etiological agents that affect the health of the consumer [11]. Foodborne diseases present a variety of gastrointestinal symptoms, such as nausea, vomiting, diarrhea, abdominal pain, and fever, and in some cases, they may have complications such as sepsis, meningitis, abortions, Reiter's syndrome, Guillain-Barré syndrome, cancer, or death $[8,11]$. These diseases affect mostly children, pregnant women, people with compromised immune systems, and the elderly [11]. Estimations from the World Health Organization (WHO) indicate that 1 in 10 people are affected annually by these diseases through food worldwide, with 420,000 deaths, especially in children [12]. Thus, FDs are considered a public health challenge worldwide due to their morbidity and mortality, as well as their negative effects on productivity, trade, costs in health services, implementation, and monitoring of food safety $[7,11,13,14]$.

The factors that have been related to an increase in the incidence of these diseases are changes in lifestyle, changes in eating habits, socioeconomic level, and aging of the population, among others $[14,15]$. Approximately 250 causative agents of FD have been described, including metals, toxins, bacteria, viruses, fungi, parasites, and prions [14]. Among these, bacteria are mostly related to cases and outbreaks $[9,11]$.

\section{Fish and Tilapia}

In a generic way, "fish" (fish, crustaceans, mollusks, and algae, among others) refers to all food extracted from oceanic or continental waters that can be used for human or animal nutrition [16].

Fish is considered a food of high nutritional value and an essential part of the human diet, as it is a source of proteins of biological value, unsaturated lipids, vitamins, and minerals $[16,17]$. The origins of the fish destined for human consumption are capture fishing and aquaculture. These activities reported a worldwide production of 178.5 million tons in 2018, with a per capita consumption of $20.5 \mathrm{~kg}$ [18]. Currently, fish is marketed for consumption in different presentations, be it whole, gutted and/or fresh fillet, refrigerated, frozen, modified atmosphere packaging, canned, smoked, salted, dehydrated, and derived products (surimi). [19-21].

However, fish are highly susceptible to deterioration and contamination, and processes of autolysis, oxidation, and microbiological activity intervene in deterioration and affect quality $[16,17]$. The quality, nutritional value, and safety of the fish are related to the species, age, habitat, type of feeding, capture conditions, storage conditions, handling, transport conditions, and distribution (Table 1) [17].

Tilapia, one of the finned fish with the highest global production, mainly through aquaculture, comprises $10.3 \%$ of the total production, with 5,555.4 thousand tons [18]. Through capture fisheries in continental waters, within the 4 groups of species that represent $85 \%$ of the total fishing worldwide, tilapia and other cichlids represent the second largest production group, behind carp, barbel, and other cyprinids, with stable catches between 700,000 and 850,000 tons per year, the main producers being various countries in Asia (China, India, and Bangladesh, among others) and Africa (Nigeria, Egypt, Chad, Kenya) [18]. Tilapia is a teleost fish of the Perciforme order of the Cichlidae family, native to Africa, that inhabits most of the tropical regions of the world and that, according to parental care patterns, is classified into three genera: Tilapia, Oreochromis, and Sarotherodon $[26,27]$. Species of the genus Oreochromis (O. niloticus, $O$. aureus, $O$. mossambicus) and their interspecific hybrids (red tilapia) are generally cultivated since these fish can tolerate high densities, their growth is fast, they are resistant to diseases and adaptable to captivity, and they accept 
TABLE 1: Different hazards to the safety of fish and fish products intended for human consumption [22-25].

\begin{tabular}{|c|c|c|}
\hline & Microorganism & Causal agents of food-borne diseases \\
\hline \multirow{9}{*}{ Hazards } & Bacteria & $\begin{array}{c}\text { Vibrio sp., Salmonella spp., Shigella sp., Plesiomonas shigelloides, Edwardsiella tarda, Listeria } \\
\text { monocytogenes, Staphylococcus aureus, Escherichia coli, Clostridium botulinum, Clostridium } \\
\text { perfringens, Bacillus cereus, Campylobacter jejuni, Aeromonas hydrophila. }\end{array}$ \\
\hline & Fungi & Fusarium spp., Aspergillus spp., Penicillium spp. \\
\hline & Viruses & $\begin{array}{l}\text { Hepatitis A, hepatitis E, adenovirus, norovirus, astrovirus, rotavirus, enterovirus. } \\
\text { Gnathostoma }\end{array}$ \\
\hline & Parasites & $\begin{array}{r}\text { Contracaecum sp., Diphyllobothrium sp., Phagicola sp., Clonorchis sp., Paragonimus sp., } \\
\text { Heterophyes sp., Cryptosporidium sp. }\end{array}$ \\
\hline & & Chemical compounds \\
\hline & Biotoxins & $\begin{array}{c}\text { Tetrodotoxin, ciguatera (ciguatoxin, scaritoxin, maitotoxin, palytoxin, and okadaic acid), } \\
\text { gempilotoxin, and mycotoxins }\end{array}$ \\
\hline & Heavy metals & , copper, mercury \\
\hline & Organic compounds & $\begin{array}{l}\text { Polycyclic aromatic hydrocarbons, polychlorinated biphenyls, polybrominated diphenyl ethers, } \\
\text { dioxins, pesticides, microplastics, antibiotics, and hormones }\end{array}$ \\
\hline & $\begin{array}{l}\text { Nitrogen compounds biogenic } \\
\text { amines }\end{array}$ & $\begin{array}{l}\text { Histamine, putrescine, and cadaverine by the decarboxylation of histidine, ornithine, and lysine, } \\
\text { respectively, in activities mediated by bacterial metabolism }\end{array}$ \\
\hline
\end{tabular}

balanced feeding diets, in addition to the fact that meat is of high quality and can be sold at an affordable price, making it one of the aquaculture products with the greatest international commercialization, either as a complete product or fillet [26].

3.1. Fish Microbiology. The microorganisms in fish, both in free-living and captured specimens, are normally present in the skin $\left(10^{2}-10^{7} \mathrm{CFU} / \mathrm{cm}^{2}\right)$ and in gills and intestines $\left(10^{3}\right.$ and $10^{9} \mathrm{CFU} / \mathrm{g}$ ) and have preponderant effects on quality, deterioration, and safety [28]. The pathogenic bacteria present in fish that are important in the deterioration and safety of fish can be classified into two groups. Group 1: native bacteria, which are widely distributed in aquatic environments around the world, where water temperature has a selective effect. Among these are Clostridium botulinum, Listeria monocytogenes, Vibrio sp., Aeromonas hydrophila, and Plesiomonas shigelloides. Group 2: nonautochthonous bacteria that are found in fish that are derived from fecal contamination of natural waters or aquatic environments or of the products during their elaboration. Some examples of these microorganisms are Staphylococcus aureus, E. coli, Salmonella spp., and Shigella spp. and other enterobacteria [4]. In the case of tilapia microbiota, various studies around the world have reported the presence of mainly Gram-negative microorganisms, many of which are pathogens for humans, such as Aeromonas spp., Plesiomonas shigelloides, Shewanella putrefaciens, Pseudomonas spp., Vibrio spp., Citrobacter freundii, and Escherichia coli, as well as different Gram-positive microorganisms, such as Bacillus spp., Streptococcus sp., and Staphylococcus spp. [29-32].

\section{Plesiomonas}

The genus Plesiomonas is made up of a single species, Plesiomonas shigelloides, a Gram-negative bacillus belonging to the Enterobacteriaceae family, which has the following characteristics and functions: it is 0.3 to $1.0 \mu \mathrm{m}$ in diameter by 2 to $3 \mu \mathrm{m}$ in length; it has a genome size of $3.4 \mathrm{Mbp}$; it has a $\mathrm{G}+\mathrm{C}$ content is $51 \%(\mathrm{~mol} \%)$; it is chemoorganotrophic with a respiratory and fermentative metabolism; it is facultative anaerobic; it is nonsporulated; it is mobile with a polar flagella; it presents somatic antigens "O" and flagellar " $\mathrm{H}$ " and recognizes $102 \mathrm{O}$ and 51 flagellar $\mathrm{H}$ antigens; it produces the enzymes oxidase, catalase, and tryptophanase; it does not hydrolyze starch; it ferments inositol, glucose, and some other carbohydrates without producing gas; it decarboxylates lysine and ornithine; it mediates arginine dihydrolysis; and it is sensitive to vibriostatic $\mathrm{O} / 129$ [27, 32-39].

The bacterium has a growth temperature between $8^{\circ} \mathrm{C}$ and $45^{\circ} \mathrm{C}$, with an optimum temperature between $25^{\circ} \mathrm{C}$ and $38^{\circ} \mathrm{C}$ and an optimum growth $\mathrm{pH}$ in the range of 4 to 9 , and can grow in salt concentrations ranging from 0 to $4 \%$ [34-39].

$P$. shigelloides has been isolated from the intestinal contents of humans and animals. Likewise, it is a common inhabitant of aquatic environments, especially in tropical and subtropical regions, including fresh and salt water. Therefore, it can be incorporated in various food products, being found in fresh and salty fish and shellfish; water and food are considered transmission vehicles [29-31, 33-40]. Thus, the consumption of raw or undercooked fish and shellfish is considered one of the main risk factors for infection $[27,36,40]$. Likewise, $P$. shigelloides can cause infections in humans by being present in and transported by untreated water used for drinking, water in recreational facilities, or water used to wash food that is consumed without cooking or heating [34].

Virulence factors that promote disease by this microorganism in humans and animals include the presence of exopolysaccharides for biofilm formation, hydrophobic characteristics of the bacterial surface, adhesion to the host cell surface through fimbriae, mobility through flagella, glycocalyx, DNase, gelatinase, and elastases that allow bacteria to break down proteins of the cell matrix, leading to tissue invasion and spread of infection, enterotoxins, cholera-like toxins, endotoxins (lipopolysaccharide structure, highly immunogenic), cytotoxins, cardiotoxins, 
$\beta$-hemolysins, hemagglutinins, iron acquisition systems, and the presence of a plasmid $>120 \mathrm{mDa}$ that assists in cell invasion [31-36, 41-43].

The disease caused by $P$. shigelloides is gastroenteritis, and the infectious dose is estimated to be greater than $10^{6} \mathrm{CFU}$. Ingestion does not always cause this disease, which is generally self-limited and accompanied by fever, chills, abdominal pain, nausea, diarrhea, and/or vomiting; in severe cases, the diarrheal stools can be yellowish green, foamy, and bloody. $P$. shigelloides is also capable of causing septicemia with a high mortality rate and other extraintestinal infections, such as cellulitis, urinary tract infections, peritonitis, meningitis, conjunctivitis, endocarditis, pneumonia, arthritis, endophthalmitis, and cholecystitis [27, 34-36, 44, 45].

The prevalence of $P$. shigelloides gastroenteritis is variable between geographic regions, with lower rates in North America and Europe and higher estimates in Southeast Asia and Africa. In addition, there is a general underestimation of Plesiomonas infections commonly because it shares clinical manifestations with other pathogens. Additionally, $P$. shigelloides is not considered for routine analysis in the clinical setting; thus, pathogenic knowledge is limited [46].

In various countries worldwide, such as Japan, Mexico, the USA, Cameroon, Ecuador, Thailand, Nigeria, Cuba, and China, $P$. shigelloides is a clinically relevant pathogen, with numerous cases and outbreaks of diarrhea and gastroenteritis reported that cover all ages ranging from $<5$ to $>60$ years. Infections present a seasonal aspect, where the most reported cases are in the warm months of the year when freshwater temperatures increase, allowing for greater microbial growth and contamination of the waters. In addition, inadequate hygiene practices in food preparation and consumption of untreated water or raw or undercooked fish and shellfish prior to illness showed causal relationships [1, 36, 46-49].

The incidence of health-related Plesiomonas infections in immunosuppressed people has been reported to be increasing, especially considering current lifestyles. It is estimated that climate change and global warming promote an increase in the incidence of infectious diseases (including Plesiomonas) transmitted mainly by water [46].

Treatment for infection by Plesiomonas shigelloides generally consists of oral rehydration, while in severe cases, the use of antimicrobials such as norfloxacin, trimethoprim, azithromycin, ceftriaxone, or ciprofloxacin is recommended $[36,50]$. In recent years, the isolation of Plesiomonas from the aquatic environment showing resistance to several antimicrobials, many of which are used in the treatment of infections, has been reported; it has been pointed out that antimicrobial resistance is the product of contamination by human activities, which has become a serious threat to public health and to these reservoir environments [51-53].

4.1. Plesiomonas and Tilapia. Plesiomonas is not considered part of the normal microbiota of humans, although the opposite is true for freshwater fish from aquaculture and the environment, such as tilapia, which are indicated as a primary reservoir, as well as the water and sediment of their habitat. Plesiomonas acts as a facultative or opportunistic pathogen in fish, causing epizootic outbreaks associated with stress-promoting factors such as handling, poor hygiene conditions, a high amount of organic matter in ponds, and an increase in water temperature, ultimately triggering high mortality rates and loss in aquaculture productivity $[27,29,36,40,54,55]$. Considering the increases in the fishing and aquaculture production and commercialization of these fish around the world, the focus has been on the safety and control of these products and their prevention since they are a potential source of diseases to humans $[40,54,56]$.

\section{Control and Prevention of Diseases in Humans due to Plesiomonas shigelloides}

Contamination of food by $P$. shigelloides and subsequent human diseases are generally related to exposure to contaminated water sources along the food chain, as well as to the consumption of raw or undercooked fish and shellfish [35].

For the development and implementation of control and prevention actions, an interdisciplinary orientation is required that involves actors in the food production and supply chain, such as health regulatory authorities, producers, industrialists, and merchants. These actions involve the surveillance and sanitary regulation of products, implementation of good practices in primary production and manufacturing, and the Hazard Analysis and Critical Control Points (HACCP) system, with the latter being one of the main preventive control measures. Likewise, education and awareness actions on the hygiene and microbiological safety of food are necessary, focused on handlers and final consumers [7, 35, 57].

At a global level, it is important to establish and harmonize the quality and safety of food to contribute to the control and prevention of food-borne diseases due to contamination by different causal agents of biological origin, such as various enterobacteria, including Plesiomonas. The Food and Agriculture Organization of the United Nations (FAO) and the World Health Organization (WHO) created the Codex Alimentarius, which is a set of codes of practice, guidelines, and standards on issues related to hygiene, contaminants, labeling, presentation, and additives that are focused on raw, semiprocessed, or processed foods for distribution to the consumer or as raw material. Codex Alimentarius standards are internationally accepted to guarantee food safety and facilitate global trade [58]. In the case of fish and fish product safety, some components of the Codex Alimentarius normative framework include the general principles of food hygiene (CXC 1-1969) [59], the code of practice for fish and fishery products (CXC 52-2003) [60], and standards for quick-frozen finned fish, both uneviscerated and eviscerated (CODEX STAN 36-1981) [61], among others.

Different countries around the world, such as the European community, have established food safety measures for human consumption through different regulations (EC), 


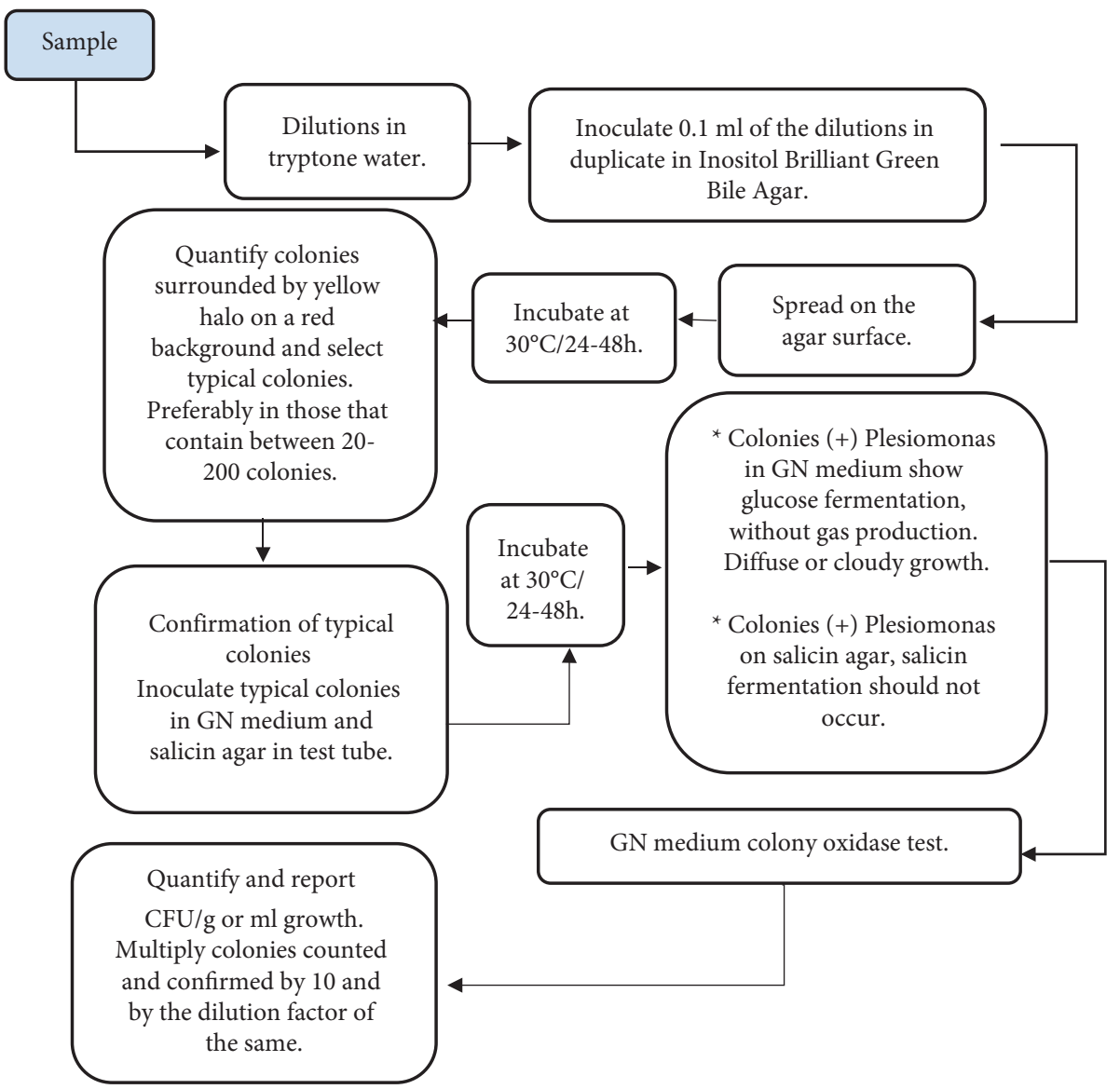

Figure 1: Direct plaque quantification of Plesiomonas in food samples [75]. * GN medium consists of 3 layers of approximately $2 \mathrm{~cm}$ each, placed in a sterile culture tube. The bottom layer is bile and red violet glucose agar. The middle layer is agar-water, and the top layer is sulfide indole motility (SIM) agar. * Glucose fermentation in positive GN medium (turning of the bile and red violet glucose agar medium in the lower layer of the tube). ${ }^{*}$ P. shigelloides is $\mathrm{SH}_{2}$ - and indole-positive, but these characteristics are not shown in GN medium. ${ }^{*}$ In GN medium, the mobile species develop, forming diffuse growth along the inoculation streaking line or more intense turbidity.

such as $\mathrm{N}^{\mathrm{o}} .178,852,853,854$, and 2073 [62-66], the latter based on microbiological criteria to be met in the production and commercialization of fish and fish products, but these measures lack a section referring to Plesiomonas shigelloides, unlike other enterobacteria, such as Salmonella spp., and Vibrio spp., making it necessary to analyze the incorporation of $P$. shigelloides in the regulatory framework for fish products. Meanwhile, in Latin America, countries such as Mexico have sanitary regulations for fish and fish products through NOM-242-SSA1-2009 [67], a standard in which, unlike Enterobacteriaceae, such as Salmonella spp., and Vibrio spp., which must be absent from the product, E. coli should be at a maximum of 400 MPN (most probable number)/g. However, this standard does not present microbiological criteria applicable to Plesiomonas shigelloides. The NOM-251-SSA1-2009 standard [68] establishes hygiene practices for the processing of food, beverages, or food supplements and their raw materials to avoid their contamination throughout their processing and involves the implementation of HACCP systems, and the NOM-128SSA1-1994 standard [69] specifically establishes the application of a system of risk analysis and control of critical points in the industrial plant that processes fish products.
For the particular case of fishery products such as refrigerated fresh tilapia and frozen fresh tilapia, the standards NMX-F-578-SCFI-2001 [70] and NMX-F-579-SCFI-2001 [71], respectively, establish product quality specifications for human consumption, including microbiological analyses for evaluation. However, none of the above standards considers the analysis of Plesiomonas.

5.1. Food Analysis in the Laboratory. The microbiological analysis of food is carried out with main three objectives: quality control and evaluation of shelf life, review of hygiene procedures in handling and production processes, and control and prevention of diseases through food [72]. $P$. shigelloides can be isolated from environmental, clinical, or food samples using various differential and selective culture media such as Pseudomonas-Aeromonas selective (GSP) agar, thiosulfate citrate bile sucrose (TCBS) agar, and inositol-brilliant-green-bile salt (IBB) agar, as well as some culture media generally used for Enterobacteriaceae such as Rimler-Shotts agar, MacConkey (MAC), xylose lysine decarboxylase (XLD), or Hektoen (HE) agar; in the latter, the appearance of typical colonies is variable due to its slow fermentation of lactose [34-36, 73, 74]. 


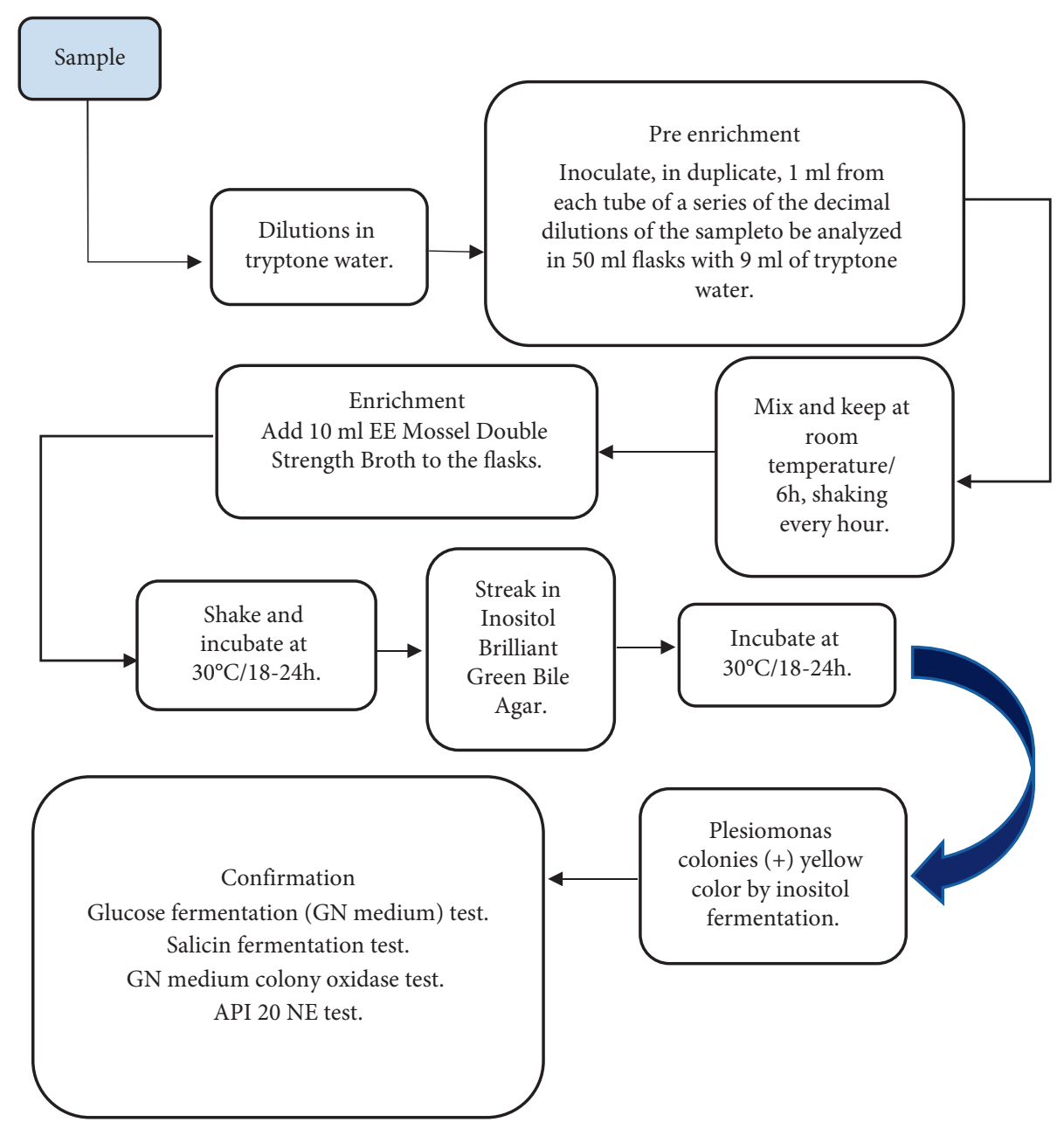

Figure 2: Presence-absence test with enrichment in selective medium [75].

The isolation and detection techniques of $P$. shigelloides in food are based on direct sowing and counting in plates with selective culture medium, generally using a previous enrichment phase with alkaline peptone water $\mathrm{pH} 8.6$, with or without the addition of $1-3 \% \mathrm{NaCl}$, bile peptone broth, tetrathionate broth, Mossel EE broth, or others due to the stress to which the microorganism is subjected in the different phases through which the food passes from its production to consumption $[34,36,73-75]$. The culture media generally used for selective isolation are inositol-bright green-bile salt (IBB) agar and cefsulodin-irgasan-novobiocin (CIN) agar [35, 36, 75]. Anderson et al. [75] reported two detection methods for $P$. shigelloides. A direct plate quantification method using sample dilutions and inoculation on the surface of IBB selective agar was performed, and positive inositol fermentation colonies were subsequently selected for confirmation using GN medium (Gram-negative bacteria) and salicin agar as well as different biochemical tests, such as oxidase (Figure 1). Another method reported by researchers to determine the presence or absence of Plesiomonas in food samples involves using pre-enrichment media (tryptone water), selective enrichment (EE Mossel broth), and differentials such as IBB agar, as well as biochemical confirmation tests (GN medium, salicin agar, and oxidase). The enrichment phases were preferably incorporated for the detection of the pathogen due to a possible reduced amount present, to the stress to which it was subjected in the food or to inhibit the accompanying microbiota in the sample (Figure 2). Growth inhibition in $6 \% \mathrm{NaCl}$ and biochemical tests for arginine dihydrolase and 1-histidine decarboxylase can be used to differentiate the growth of $P$. shigelloides from Vibrio spp., while the tests for lysine decarboxylase and ornithine decarboxylase differentiate $P$. shigelloides from Aeromonas spp., and the cytochrome oxidase test differentiates $P$. shigelloides from other Enterobacteriaceae (Table 2) [35, 56, 76]. Other biochemical identification tests used include indole, inositol, and glucose fermentation, production of $\beta$-hemolysis, sensitivity to vibriostatic $\mathrm{O} / 129$ or a variety of commercial kits, such as API 20E, the Vitek 2 system, or the BD Phoenix [27, 34, 36].

Within the analysis for the detection of $P$. shigelloides as an alternative to the traditional microbiological analysis, molecular techniques have been developed based on the polymerase chain reaction (PCR) with its different variants, which show greater specificity, sensitivity, reliability, and speed in the detection of the pathogen in fish and tilapia samples, and that use as targets regions of the $23 S \mathrm{rRNA}$ gene, $16 \mathrm{~S} r R N A$, gyrB, fur (ferric uptake regulator), and $h u g A$ 
Table 2: Biochemical identification among Plesiomonas, Vibrio, and Aeromonas bacteria present in fish and fish products [29-32, 75-78].

\begin{tabular}{|c|c|c|c|}
\hline \multirow{2}{*}{ Test } & \multicolumn{3}{|c|}{ Microorganism } \\
\hline & Vibrio & Aeromonas & Plesiomonas \\
\hline Oxidase & + & + & + \\
\hline Mobility & + & + & + \\
\hline Indole & + & + & + \\
\hline Mannitol & + & + & - \\
\hline O129 & S & $\mathrm{R}$ & $\mathrm{R}$ \\
\hline LDCA & + & - & + \\
\hline ODCA & $(+)$ & - & + \\
\hline ADHA & - & $(+)$ & + \\
\hline Inositol & - & - & $(+)$ \\
\hline
\end{tabular}

+: positive, -: negative, (+): late positive, S: sensitive, R: resistant. LDCA: lysine decarboxylase, ODCA: ornithine decarboxylase, ADHA: arginine dihydrolase, vibriostatic agent $\mathrm{O} / 129$.

gene, the latter encoding an outer membrane receptor required for the use of 435-bp heme iron [36, 40, 41, 55, 79]. Likewise, among the molecular tools focused on the genotyping of isolates for phylogenetic and epidemiological studies are multilocus sequence typing (MLST), random amplified polymorphic DNA (RAPD)-PCR, enterobacterial repetitive intergenic consensus (Eric)-PCR, repetitive extragenic palindromic (REP)-PCR, and pulsed field gel electrophoresis (PFGE) [80, 81]. Meanwhile, there are techniques for the identification and phenotypic characterization of bacterial isolates based on the analysis of proteins (mainly ribosomal) through the creation of a specific mass spectrum of genus and species (fingerprint) based on the sensitivity, accuracy, speed, and reproducibility of matrix-assisted laser desorption ionization-time of flight mass spectrometry (MALDI-TOF MS) [36, 82, 83].

\section{Conclusions}

Fish are considered a nutritious food that is widely produced, marketed, and consumed around the world. Tilapia is among the fish with the highest production, mainly in aquaculture destined for human consumption. Fish are highly susceptible to contamination and deterioration along the food chain by different microorganisms, such as Plesiomonas shigelloides, which is a causal agent of disease in fish, such as tilapia and humans, negatively affecting primary production and food safety. For P. shigelloides, which is common in natural and aquacultural water systems and is considered part of the microbiota of freshwater fish such as tilapia, the implementation of good hygiene practices in production, processing and preservation, and sanitary surveillance of regulatory authorities and the food industry, as well as the promotion of hygiene education in the handling and final preparation of these foods for consumption, can reduce the risk of contamination and outbreaks of foodborne diseases.

\section{Conflicts of Interest}

The authors declare that they have no conflicts of interest in the development and publication of this document.

\section{Authors' Contributions}

Alejandro De Jesús Cortés-Sánchez led the overall study activities, while the other authors contributed equally.

\section{Acknowledgments}

Alejandro De Jesús Cortés Sánchez and Luis Daniel Espinosa-Chaurand acknowledge financial support given by the National Council for Science and Technology of Mexico (CONACYT) to "Cátedra" position at CIBNOR. The development of this manuscript was supported by the National Council of Science and Technology of Mexico (CONACYT) and cátedras project-CONACYT.

\section{References}

[1] F. González Solórzano, "Importancia de la capacitación a personas que prestan servicios de alimentación, como medio para disminuir las ETAS en Costa Rica," Repertorio Científico, vol. 18, no. 1, pp. 11-16, 2015.

[2] A. B. Martínez Zazo and C. Pedrón Giner, "Conceptos básicos en alimentación," Sociedad Española de Gastroenterología, Hepatología y Nutrición Pediátrica (SEGHNP), Nutricia, Zoetermeer, Netherlands, 2016.

[3] D. V. G. S. Fernandes, V. S. Castro, A. D. Cunha Neto, and E. E. D. S. Figueiredo, "Salmonella spp. in the fish production chain: a review," Ciência Rural, vol. 48, no. 8, 2018.

[4] H. H. Huss, "Aseguramiento de la calidad de los productos pesqueros," FAO, Roma, Italy, FAO Documento Técnico de Pesca. No. 334, 1997.

[5] G. Barbosa-Cánovas and D. Bermúdez-Aguirre, "Procesamiento no térmico de alimentos," Scientia Agropecuaria, vol. 1, no. 1, pp. 81-93, 2010.

[6] A. D. J. Cortés-Sánchez, M. Díaz-Ramírez, P. Salgado-Cruz Ma. De la, and R. G. Hernández-Nava, "Food safety and fish production the case of Staphylococcus aureus," A Review, vol. 20, no. 4, pp. 291-306, 2020.

[7] G. Vásquez de Plata, "La contaminación de los alimentos, un problema por resolver," Salud UIS, vol. 35, no. 1, 2003.

[8] WHO, Temas de salud. Enfermedades de transmisión alimentaria. Organización mundial de la salud, WHO, Geneva, Switzerland, 2021.

[9] L. Espinosa, C. Varela, E. V. Martínez, and R. Cano, "Brotes de enfermedades transmitidas por alimentos. España, 2008-2011 
(excluye brotes hídricos)," Boletín epidemiológico semanal, vol. 22, no. 11, pp. 130-136, 2015.

[10] N. M. De la Fuente Salcido and J. E. Barboza Corona, "Inocuidad y bioconservación de alimentos," Acta Universitaria, vol. 20, no. 1, pp. 43-52, 2010.

[11] Z. Soto Varela, L. Pérez Lavalle, L. Pérez Lavalle, and D. Estrada Alvarado, "Bacteria causing of foodborne diseases: an overview at Colombia," Salud Uninorte, vol. 32, no. 1, pp. 105-122, 2016.

[12] OMS, Carga mundial de enfermedades de transmisión alimentaria: estimaciones de la OMS, Organización Mundial de la Salud (OMS), Geneva, Switzerland, 2015, https://www.who. int/foodsafety/areas_work/foodborne-diseases/ fergonepager_es.pdf?ua $=1$.

[13] A. d. J. Cortés-Sánchez, "Food, fish and campylobacteriosis," International Journal of Food Studies, vol. 9, no. 2, pp. 394406, 2020a.

[14] A. Olea, J. Díaz, R. Fuentes, A. Vaquero, and M. García, "Vigilancia de brotes de enfermedades transmitidas por alimentos en Chile," Revista Chilena de Infectología, vol. 29, no. 5, pp. 504-510, 2012.

[15] H. Rodríguez Torrens, G. Barreto Argilagos, M. Sedrés Cabrera, J. Bertot Valdés, S. Martínez Sáez, and G. Guevara Viera, "The foodborne diseases, a health problem inherited and increased in the new millennium," Revista Electrónica de Veterinaria, vol. 16, no. 8, pp. 1-27, 2015.

[16] K. M. D. P. Soares and A. A. Gonçalves, "Qualidade e segurança do pescado," Revista Do Instituto Adolfo Lutz, vol. 71, no. 1, pp. 1-10, 2012.

[17] H. G. Fuertes Vicente, F. Paredes López, and D. I. Saavedra Gálvez, "Good practice manufacturing and preservation onboard: fish safe," Big Bang Faustiniano, vol. 3, no. 4, pp. 41-45, 2014.

[18] FAO, El estado mundial de la pesca y la acuicultura 2020. La sostenibilidad en acción, Organización de las Naciones Unidas para la Alimentación y la Agricultura (FAO), Rome, Italy, 2020.

[19] F. Betancourt-Sambony, Rivera-Valencia, Francisco-Javier, and J. Girón-Hernández, "Kinetic control of the smokeflavoured salting process of tilapia fillets (Oreochromis sp)," Biotecnología en el Sector Agropecuario y Agroindustrial, vol. 19, no. 2, pp. 27-40, 2021.

[20] J. Babic Milijasevic, M. Milijasevic, and V. Djordjevic, "Modified atmosphere packaging of fish-an impact on shelf life," IOP Conference Series: Earth and Environmental Science, vol. 333, no. 1, 2019.

[21] J. R. Martínez Álvarez, "El pescado en España: consumo histórico de un alimento básico. En: el pescado y la dieta 6 . Nutricion y Salud. Edición y Coordinación: José Antonio Pinto Fontanillo. Nueva imprenta, S.A. Madrid, España," 2008, http://www.madrid.org/bvirtual/BVCM009018.pdf.

[22] N. Seltenrich, "New link in the food chain?" Marine Plastic Pollution and Seafood Safety, vol. 123, 2015.

[23] A. L. Andrady, "The plastic in microplastics: a review," Marine Pollution Bulletin, vol. 119, no. 1, pp. 12-22, 2017.

[24] A. D. J. Cortes Sanchez, R. Garza Torres, and L. D. Espinosa Chaurand, "Gıda, balık ve mikotoksinler," Acta Aquatica Turcica, vol. 16, no. 4, pp. 571-584, 2020 b.

[25] A. D. J. Cortés-Sánchez, "Food, fish and diseases transmitted to the consumer," Journal of Advanced Laboratory Research in Biology, vol. 11, no. 2, pp. 16-23, 2020 b.

[26] J. Jácome, C. Quezada Abad, O. Sánchez-Romero, J. E. Pérez, and M. Nirchio, "Tilapia en Ecuador," Revista Peruana de Biologia, vol. 26, no. 4, pp. 543-550, 2019.
[27] V. Sierralta Chichizola, E. Mayta Huatuco, and J. León Quispe, "Primer Registro de Plesiomonas shigelloides como Patógeno Oportunista de Tilapia Oreochromis niloticus (Linnaeus, 1758) en una Piscigranja de Lima, Perú," Revista de Investigaciones Veterinarias del Perú, vol. 27, no. 3, pp. 565572, 2016.

[28] H. H. Huss, "El Pescado Fresco: Su Calidad y Cambios de su Calidad," FAO documento técnico de pesca 348, Organización de las Naciones Unidas para la Agricultura y la Alimentación (FAO), Rome, Italy, 1998, http://www.fao.org/3/v7180s/ v7180s00.htm\#Contents.

[29] L. M. Molinari, D. D. O. Scoaris, R. B. Pedroso et al., "Bacterial microflora in the gastrointestinal tract of Nile tilapia, Oreochromis niloticus, cultured in a semi-intensive system," Acta Scientiarum. Biological Sciences, vol. 25, no. 2, pp. 267-271, 2003.

[30] M. Fuentes, J. Valladares, G. Grass, and Y. Pico, "Microbial of the public health interest of Oreochromis spp. (Red tilapia) cultured in freshwater floating cages," Revista Cubana de Investigaciones Pesqueras, vol. 28, no. 2, pp. 74-80, 2011.

[31] R. Pakingking, P. Palma, and R. Usero, "Quantitative and qualitative analyses of the bacterial microbiota of tilapia (Oreochromis niloticus) cultured in earthen ponds in the Philippines," World Journal of Microbiology and Biotechnology, vol. 31, no. 2, pp. 265-275, 2015.

[32] J. A. Valenzuela-Armenta, S. P. Díaz-Camacho, J. A. Cabanillas-Ramos et al., "Microbiological analysis of Tilapia and water in aquaculture farms from sinaloa," Biotec, vol. 20, no. 1, pp. 20-26, 2018.

[33] E. Gámez Frómeta, A. Sanchén Casas, U. del Risco Barrios, and R. I. Hernández Cisneros, "Isolation of Plesiomonas shigelloides cultures of patients with acute diarrheal disease," Revista Archivo Médico de Camagüey, vol. 9, no. 3, pp. 14-25, 2005.

[34] J. P. Falcão, A. A. Gibotti, R. A. Souza, F. Campioni, and D. P. Falcão, "Plesiomonas shigelloides: um enteropatógeno emergente?" Revista de Ciências Farmacêuticas Básica e Aplicada, vol. 28, no. 2, pp. 141-151, 2007.

[35] C. J. Grim, "Aeromonas and Plesiomonas," Foodborne Infections and Intoxications, vol. 13, pp. 229-237, 2013.

[36] J. M. Janda, S. L. Abbott, and C. J. McIver, "Plesiomonas shigelloides revisited," Clinical Microbiology Reviews, vol. 29, no. 2, pp. 349-374, 2016.

[37] J. M. Janda, "Plesiomonas," in Bergey's Manual of Systematics of Archaea and Bacteria, M. E. Trujillo, S. Dedysh, P. DeVos et al., Eds., Wiley, Hoboken, NJ, USA, 2015.

[38] A. K. Bhunia, "Opportunistic and emerging foodborne pathogens: Aeromonas hydrophila, Plesiomonas shigelloides, cronobacter sakazakii, and Brucella abortus," in Foodborne Microbial Pathogens, pp. 343-350, Springer, New York, NY, USA, 2018.

[39] E. Rodríguez and F. Antillón, “Aeromonas spp. y Plesiomonas shigelloides en bivalvos, cieno y aguas del Golfo de Nicoya, Costa Rica," Revista de Biologia Tropical, vol. 37, no. 1, pp. 69-73, 1989.

[40] M. Moreno, L. Yelitza Medina, J. D. Álvarez Rivera, and M. M. G. Obregón José, "Detección de Plesiomonas shigelloides mediante la PCR en tilapias silvestres (Oreochromis mossambicus) y cultivadas (tetrahíbrido O. mossambicus $\times$ O. urolepis hornorum $\times$ O. niloticus $\times$ O. aureus) en Venezuela," Revista Científica, vol. 16, no. 5, pp. 459-465, 2006.

[41] M. S. Edwards, R. W. McLaughlin, J. Li et al., "Putative virulence factors of Plesiomonas shigelloides," Antonie Van Leeuwenhoek, vol. 112, no. 12, pp. 1815-1826, 2019. 
[42] L. Bravo, Y. Correa, J. F. Clausell et al., "Virulence factors and in vitro susceptibility of Plesiomonas shigelloides isolated from diarrhea episodes in Cuba," Revista chilena de infectología, vol. 26, no. 3, pp. 233-238, 2009.

[43] A. Salerno, I. Čižnár, K. Krovacek et al., "Phenotypic characterization and putative virulence factors of human, animal and environmental isolates of Plesiomonas shigelloides," Folia Microbiologica, vol. 55, no. 6, pp. 641-647, 2010.

[44] M. A. Pence, "The brief case: wound infection with Plesiomonas shigelloides following a freshwater injury," Journal of Clinical Microbiology, vol. 54, no. 5, pp. 1180-1182, 2016.

[45] F. M. M. Barragán, D. P. Gómez, M. C. Osorio et al., "El microcosmo de la ciudad de Bogotá," Letras ConCiencia TecnoLógica, pp. 55-65, Escuela Tecnológica Instituto Técnico Central, Bogotá, Colombia, 2018.

[46] T. C. Ekundayo and A. I. Okoh, "A global bibliometric analysis of Plesiomonas-related research (1990-2017)," PLoS One, vol. 13, no. 11, Article ID e0207655, 2018.

[47] E. Gámez Frómeta, A. Sanchén Casas, U. del Risco Barrios, and R. I. Hernández Cisneros, "Aislamiento de Plesiomonas shigelloides en pacientes con enfermedad diarreica aguda," Archivo Médico de Camagüey, vol. 9, no. 3, 2005.

[48] X. Chen, Y. Chen, Q. Yang et al., "Plesiomonas shigelloides infection in Southeast China," PLoS One, vol. 8, no. 11, Article ID e77877, 2013.

[49] H. C. Cecilia, A. A. M. Guadalupe, and C. E. Graciela, "Situación de las enfermedades gastrointestinales en México," Enfermedades Infecciosas Y Microbiología, vol. 31, no. 4, p. 137, 2011.

[50] D. R. Murdoch and S. D. Lang, "Plesiomonas Shigelloides," 2018, http://www.antimicrobe.org/b224.

[51] I. M. Adesiyan, M. A. Bisi-Johnson, A. O. Ogunfowokan, and A. I. Okoh, "Incidence and antimicrobial susceptibility fingerprints of Plesiomonas shigelliodes isolates in water samples collected from some freshwater resources in Southwest Nigeria," The Science of the Total Environment, vol. 665, pp. 632-640, 2019.

[52] A. F. M. Martins, T. L. Pinheiro, A. Imperatori et al., "Plesiomonas shigelloides: a notable carrier of acquired antimicrobial resistance in small aquaculture farms," Aquaculture, vol. 500, pp. 514-520, 2019.

[53] T. C. Ekundayo and A. I. Okoh, "Antimicrobial resistance in freshwater Plesiomonas shigelloides isolates: implications for environmental pollution and risk assessment," Environmental Pollution, vol. 257, Article ID 113493, 2020.

[54] M. Nadirah, H. H. Ruhil, K. C. A. Jalal, and M. Najiah, "Occurrence of Plesiomonas shigelloides in cultured red hybrid tilapia (Oreochromis niloticus) from tropical rivers, east coast Malaysia," Pakistan Journal of Biological Sciences, vol. 15 , no. 12 , pp. 600-603, 2012.

[55] R. G. Nisha, V. Rajathi, R. Manikandan, and N. M. Prabhu, "Isolation of Plesiomonas shigelloides from infected cichlid fishes using 16S rRNA characterization and its control with probiotic Pseudomonas sp," Acta Scientiae Veterinariae, vol. 42, no. 1, pp. 1-7, 2014.

[56] A. Newaj-Fyzul, A. Mutani, A. Ramsubhag, and A. Adesiyun, "Prevalence of bacterial pathogens and their anti-microbial resistance in tilapia and their pond water in Trinidad," Zoonoses and Public Health, vol. 55, no. 4, pp. 206-213, 2008.

[57] OMS, Manual sobre las cinco claves para la inocuidad de los alimentos, Organización Mundial de la Salud (OMS), Geneva, Switzerland, 2007, https://www.who.int/foodsafety/ publications/consumer/manual_keys_es.pdf.
[58] Comisión del Codex Alimentarius, "Manual de procedimiento-Décima edición," Programa Conjunto FAO/OMS sobre Normas Alimentarias, FAO-Organización de las Naciones, Roma, Italy, 1997, http://www.fao.org/3/w5975s/ w5975s00.htm\#Contents.

[59] WHO, "General principles of food hygiene. CXC 1," World Health Organization (WHO), Geneva, Switzerland, 1969, http://www.fao.org/fao-who-codexalimentarius/sh-proxy/es/ ?lnk=1\&url=https\%253A\%252F\%252Fworkspace.fao.org\%25 2Fsites\%252Fcodex\%252FStandards\%252FCXC\%2B1-1969\% 252FCXC_001e.pdf.

[60] WHO, "Code of practice for fish and fishery products. CXC 52," World Health Organization (WHO), Geneva, Switzerland, 2003, http://www.fao.org/fao-who-codexalimentarius/ sh-proxy/es/?lnk=1\&url=https\%253A\%252F\%252Fworkspac e.fao.org\%252Fsites\%252Fcodex\%252FStandards\%252FCXC \%2B52-2003\%252FCXC_052e.pdf.

[61] WHO, "Standard for quick frozen finfish, uneviscerated and eviscerated. CODEX STAN 36," World Health Organization (WHO), Geneva, Switzerland, 1981, http://www.fao.org/faowho-codexalimentarius/sh-proxy/es/?lnk=1\&url=https\%253 A\%252F\%252Fworkspace.fao.org\%252Fsites\%252Fcodex\%2 52FStandards\%252FCXS\%2B36-1981\%252FCXS_036e.pdf.

[62] Regulation (EC) No 178/2002 Of The European Parliament And Of The Council Of 28 January 2002, Laying Down The General Principles And Requirements Of Food Law, Establishing The European Food Safety Authority And Laying Down Procedures In Matters Of Food Safety, Official Journal of the European Communities, Maastricht, Netherlands, 2002, https:// eur-lex.europa.eu/legal-content/EN/TXT/PDF/?uri=CELEX:3 2002R0178\&from $=$ ES.

[63] Regulation (EC) No 852/2004 Of The European Parliament And Of The Council Of 29 April 2004, On The Hygiene Of Foodstuffs, Official Journal of the European Union, Maastricht, Netherlands, 2004, https://eur-lex.europa.eu/legalcontent/EN/TXT/PDF/?uri=CELEX:32004R0852\&from=ES.

[64] Regulation (EC) No 853/2004 of the European Parliament and of the Council of 29 April 2004, Laying Down Specific Hygiene Rules for on the Hygiene of Foodstuffs, Official Journal of the European Union, Maastricht, Netherlands, 2004, https://eurlex.europa.eu/legal-content/EN/TXT/PDF/?uri=CELEX:3200 4R0853\&from $=\mathrm{ES}$.

[65] Regulation (EC) No 854/2004 of the European parliament and of the council of 29 April 2004, Laying Down Specific Rules For The Organization Of Official Controls On Products Of Animal Origin Intended For Human Consumption, Official Journal of the European Union, Maastricht, Netherlands, 2004, https:// eur-lex.europa.eu/legal-content/EN/TXT/PDF/?uri=CELEX: 32004R0854\&from=ES.

[66] Commission Regulation (EC) No 2073/2005, Microbiological Criteria For Foodstuffs, Official Journal of the European Union, Maastricht, Netherlands, 2005, https:/eur-lex.europa. eu/legal-content/EN/TXT/PDF/?uri=CELEX:32005R2073\&f rom $=\mathrm{ES}$.

[67] NOM-242-SSA1-2009, Productos y servicios. Productos de la pesca frescos, refrigerados, congelados y procesados. Especificaciones sanitarias y métodos de prueba, Norma Oficial Mexicana, México City, México, 2009, http://dof.gob.mx/ nota_detalle.php? codigo $=5177531 \&$ fecha $=10 / 02 / 2011$.

[68] NOM-251-SSA1-2009, Prácticas de higiene para el proceso de alimentos, bebidas o suplementos alimenticios, Norma Oficial Mexicana, México City, México, 2009, https://www.dof.gob. mx/normasOficiales/3980/salud/salud.htm. 
[69] NOM-128-SSA1-1994, Bienes y servicios. Que establece la aplicación de un sistema de análisis de riesgos y control de puntos críticos en la planta industrial procesadora de productos de la pesca.Norma Oficial Mexicana, México City, México, 1994, https://www.gob.mx/cms/uploads/attachment/file/ 311380/NOM_128_SSA1.pdf.

[70] NMX-F-578-SCFI-2001, Fish Products-Refrigerated Fresh tilapia-Specifications, Secretaria de Economia, México City, México, 2001, https://caisatech.net/uploads/XXI_2_MXD_ C10_NMX-F-578-SCFI-2001_R0_7MAR2001.pdf.

[71] NMX-F-579-SCFI-2001, Fish Products-Frozen Fresh TilapiaSpecifications, Secretaria de Economia. Gobierno de Mexico, México City, México, 2001, https://caisatech.net/uploads/ XXI_2_MXD_C10_NMX-F-579-SCFI-2001_R0_7MAR2001. pdf.

[72] A. L. Cruces Martínez, E. I. Juárez Arroyo, A. Ortegón Ávila et al., Métodos Microbiológicos Para el análisis de Alimentos, Universidad Nacional Autónoma de México, México City, México, 2021.

[73] J. C. Sanz, M. A. Usera, J. Reina, L. Cardeñoso, and F. Vasallo, "7. Gastroenteritis bacterianas víricas, parasitarias y toxi infecciones alimentarias," Procedimientos en Microbiología Clínica, Recomendaciones de la Sociedad Española de Enfermedades Infecciosas y Microbiología Clínica, 1994, https://www.seimc.org/contenidos/documentoscientificos/ procedimientosmicrobiologia/seimcprocedimientomicrobiologia7.pdf.

[74] C. S. Pereira, C. d. A. Possas, C. M. Viana, and D. d. P. Rodrigues, "Aeromonas spp. e Plesiomonas shigelloides isoladas a partir de mexilhões (Perna perna) in natura e pré-cozidos no Rio de Janeiro, RJ," Ciência e Tecnologia de Alimentos, vol. 24, no. 4, pp. 562-566, 2004.

[75] P. Anderson, M. Del Rosario, and V. Calderón Pascual, Microbiología alimentaria. Metodología analítica para alimentos y bebidas. Segunda edición, Editorial Diaz de Santos, Madrid, Spain, 2000, https://books.google.com.mx/books? id=9EIfkks8uxMC\&printsec

$=$ frontcover $\& \mathrm{hl}=\mathrm{es} \# \mathrm{v}=$ onepage $\& \mathrm{q} \& \mathrm{f}=$ false.

[76] G. Algorta and F. Schelotto, "Principales grupos de bacilos gramnegativos no exigentes," Temas de Bacteriología y Virología médica, vol. 2, pp. 315-338, Universidad de la República, Montevideo, Uruguay, 2006, http://higiene1. higiene.edu.uy/html/www/bacvir/materiales/cefa/2008/gram negativosnoexigentes.pdf.

[77] F. Silva O, “Aeromonas spp," Revista chilena de infectología, vol. 28, no. 2, pp. 157-158, 2011.

[78] W. Silva San Cristóbal, A. Olea, V. Cachicas Cubillos et al., Manual de Procedimientos Aislamiento, Identificación y Caracterización de Vibrio parahaemolyticus. Departamento Laboratorios Biomédicos. Sección Bacteriología (ISP). Departamento de Salud Ambiental. Sección Microbiología de Alimentos. División de Epidemiología (Minsal) Ministerio de Salud, Instituto de Salud Pública, , Chile, 2008, https://www.medicatec.com/arg/files/Manual\%20de\%20Procedim.\%20Chrom.Vib rio\%20-\%20Chile1.pdf.

[79] S. Rodríguez-Rodríguez and J. A. Santos, "Detection and characterization of the ferric uptake regulator (Fur) gene in Plesiomonas shigelloides," Letters in Applied Microbiology, vol. 66, no. 4, pp. 347-351, 2018.

[80] C. González-Rey, A. Siitonen, A. Pavlova, I. Ciznar, S. B. Svenson, and K. Krovacek, "Molecular evidence of Plesiomonas shigelloides as a possible zoonotic agent," Folia Microbiologica, vol. 56, no. 2, pp. 178-184, 2011.
[81] Z. Yin, S. Zhang, Y. Wei et al., "Horizontal gene transfer clarifies taxonomic confusion and promotes the genetic diversity and pathogenicity of Plesiomonas shigelloides," mSystems, vol. 5, pp. e00448-20, 2020.

[82] R. Kolínská, M. Dřevínek, E. Aldová, and H. Žemličková, "Identification of Plesiomonas spp.: serological and MALDITOF MS methods," Folia Microbiologica, vol. 55, no. 6, pp. 669-672, 2010.

[83] N. Maldonado, C. Robledo, and J. Robledo, "MALDI-TOF mass spectrometry in clinical microbiology laboratories," Infectio, vol. 22, no. 1, pp. 35-45, 2018. 